\title{
A review on advanced physico-chemical and biological textile dye wastewater treatment techniques
}

\author{
Naresh Yadav Donkadokula $\cdot$ Anand Kishore Kola $\cdot$ Iffat Naz • \\ Devendra Saroj 10
}

Received: 2 December 2019/Accepted: 15 July 2020/Published online: 25 July 2020

(C) The Author(s) 2020

\begin{abstract}
The utilization of dyes in textile industries has enormously increased in recent years and has created several environmental problems. Currently, several methods are in practice to treat wastewaters. Effective and efficient treatment techniques before the discharge of used water in the environment are the need of the hour. This short review covers the research and recent developments in advanced wastewater treatment techniques such as nanophotocatalysis, ceramic nanofiltration membranes, and biofilms. The primary intent of this review article is to contribute the
\end{abstract}

ready-made references for the active researchers and scientists working in the field of wastewater treatment. This review has mainly focused on advanced physicochemical and biological techniques for the treatment of textile dye wastewaters. Further, the influence of various operating factors on the treatment, advantages, and disadvantages of various techniques was also discussed. The recently developed materials for wastewater treatment are also summarized based on the latest available literature.

N. Y. Donkadokula · A. K. Kola ( $\square)$

Department of Chemical Engineering, National Institute of Technology, Warangal, India e-mail: kola@nitw.ac.in

N. Y. Donkadokula $\cdot$ I. Naz · D. Saroj $(\bowtie)$ Centre for Environmental Health and Engineering (CEHE), Department of Civil and Environmental Engineering, Faculty of Engineering and Physical Sciences, University of Surrey, Guildford, Surrey GU2 7XH, UK e-mail: d.saroj@surrey.ac.uk

I. Naz

Department of Biology, Deanship of Educational Services, Qassim University, Buraidah 51452, Kingdom of Saudi Arabia 


\section{Graphic abstract}

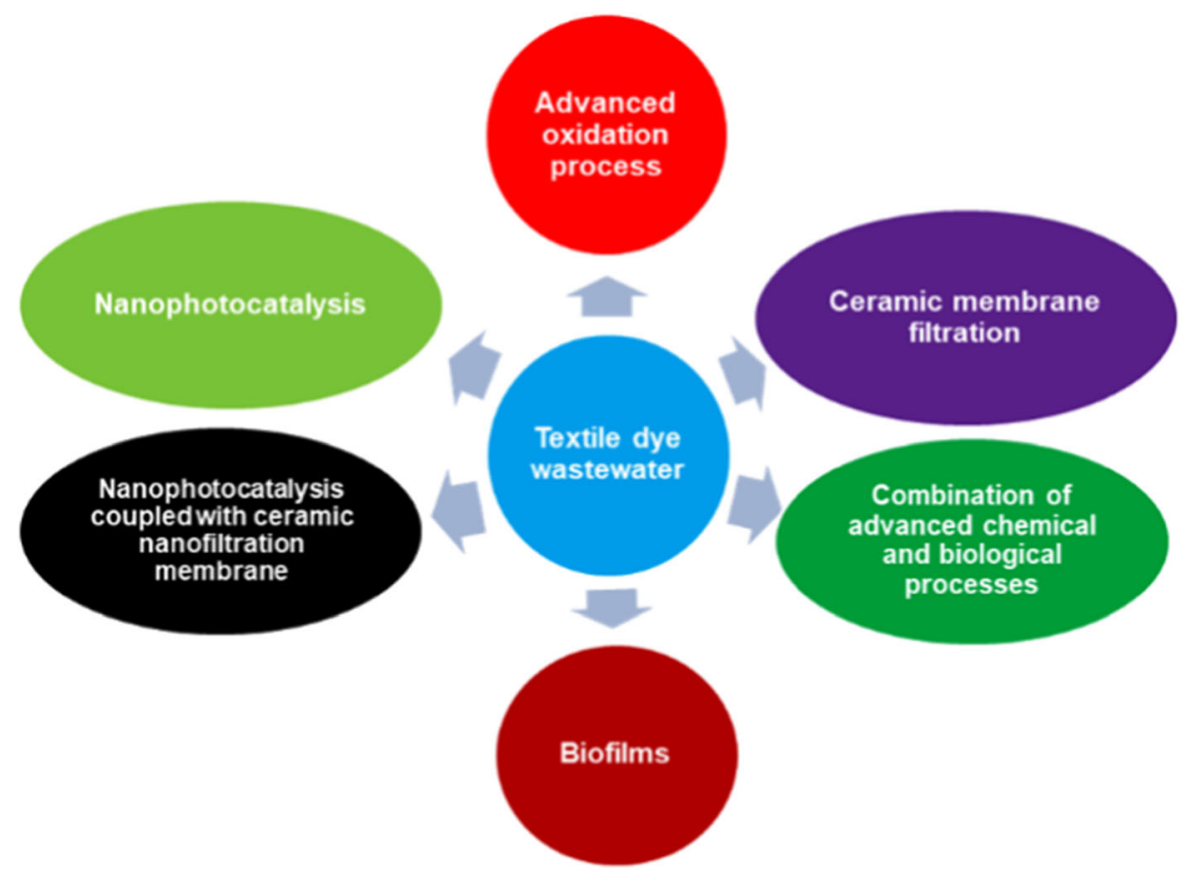

Keywords Wastewater treatment - Physicochemical - Biological treatment · Advanced oxidation processes $\cdot$ Membrane filtration $\cdot$ Nanocatalysts

\section{Introduction}

Currently, contamination of water is one of the major problems of the entire globe, due to the improper discharge of used water of the industries into the environment, high utilization of chemical fertilizers in agricultural fields, construction of roads, buildings, etc. (Sharma and Bhattacharya 2017). Further, the population growth is very expeditious, which harms the availability of drinking water to everyone. Especially, industrialization and urbanization, pollution of water have accelerated on a large scale (Saha et al. 2017). There are many chemical industries which are dealing with the dyes and among them, the large quantity of dye utilization and wastewater discharge after the process is being done by the textile industries exclusively. In the process of fiber conversion to yarn, yarn to fabric, dyeing, and finishing the textile industries use a large volume of water, numerous chemicals, auxiliary chemicals, dyes, and sizing materials (Yaseen and Scholz 2019). The usage of such harmful materials has been resulting in water contamination and environmental pollution. The water released after the fabric preparation consists of dissolved solids, color, noxious metals (chromium), printing gums (pentachlorophenol, detergents), sequestering agents (trisodium polyphosphate and sodium hexametaphosphate, chlorine, azo dyes), and stain removers $\left(\mathrm{CCl}_{4}\right.$, residual chlorine, fixing agents like; formaldehyde and benzidine). Most of the aforementioned chemicals are harmful and a threat to the environment (Hussein 2013; Ananthashankar and Ghaly 2013). Hence the wastewater is needed to be treated well before it is discharged into the environment or used for other purposes (Fallis 2007). For the dyeing process, $60-70 \%$ of azo group dyes are used by most of the textile industries and around $15-20 \%$ of the total dye is discharged into the environment during the process, which is dreadful harm to the environment (Akpan and Hameed 2009; Ouasif et al. 2013). To control such activities from the industries, the government of India through the Central Pollution Control Board (CPCB) has brought few regulations for wastewater discharge. According to the CPCB, the allowable limit of the textile dye wastewater discharge is reported as; total suspended 
solids (TSS): $100 \mathrm{mg} / \mathrm{L}$, color: $5 \mathrm{mg} / \mathrm{L}$, total dissolved solids (TDS): $2000 \mathrm{mg} / \mathrm{L}$, chemical oxygen demand (COD): $250 \mathrm{mg} / \mathrm{L}$, biochemical oxygen demand (BOD): $30 \mathrm{mg} / \mathrm{L}$ (Holkar et al. 2016). The majority of the dyes used in this process are mutagenic, toxic, and recalcitrant to the breakdown of the microbial action and also favors the formation of the carcinogenic integrated under anaerobic degradation (dos Santos et al. 2007). Furthermore, the high turbidity and the color discharged from the textile industries restrain the penetration of the oxygen and sunlight. These two sources are very much crucial for any living organism for their existence and this obstacle surely destroys the aquatic life (Crini 2006). The by-products of the dyes after degradation and the other related compounds present in the wastewater could damage human health and may lead to severe disorders such as Hemorrhage, mucous membranes, skin ulceration, and nausea (Şolpan et al. 2003). This will also have a terrible and long-lasting impact on some of the important human body parts and systems like the liver, kidney, brain, reproductive system, and central nervous system (Kavipriya et al. 2002). Thus, to minimize the toxicity, pollution, and to protect the environment, it is important to treat the dye wastewater before discharge.

In this review, advanced treatment methods of wastewater such as nanophotocatalyst application, ceramic membrane filtration, nanophotocatalysis coupled with ceramic membrane filtration and wastewater treatment using chemical and biological methods including application of biofilms, are discussed in detail.

\section{Advanced oxidation process for wastewater treatment}

Both organic and inorganic pollutants present in the wastewater are removed by a set of chemical treatment methods. Among various chemical processes for used water, the oxidation process is broadly employed and known as the advanced oxidation process (AOP). In this process, for water purification, an adequate amount of hydroxyl radicals $\left(\mathrm{OH}^{\bullet}\right)$ are generated and this notion was later expanded to sulfate radicals $\left(\mathrm{SO}_{4}^{\bullet-}\right)$ oxidative processes. Apart from the degradation of organic and inorganic pollutants, AOPs are also been studied for the pathogen and pathogenic indicators inactivation. The recalcitrant organic pollutants present in the wastewater can be swiftly degraded by the strong oxidants and hence AOPs have been considered as the best technologies for the wastewater treatment (Deng and Zhao 2015). Some of the recent studies on textile dye wastewater treatment using AOPs are discussed below in the Table 1.

Guimarães et al. (2012) studied the Reactive Blue 19 dye degradation by employing several AOPs such as the photo-Fenton process, $\mathrm{H}_{2} \mathrm{O}_{2} / \mathrm{Fe}^{2+}, \mathrm{H}_{2} \mathrm{O}_{2} / \mathrm{UV}$, peroxidation, UV, etc. The schematic experimental setup was represented below (Fig. 1). At $500 \mathrm{mg} / \mathrm{L}$ $\mathrm{H}_{2} \mathrm{O}_{2}$ and $3 \mathrm{~h}$ reaction time, $91 \%$ of dye was degraded by the $\mathrm{H}_{2} \mathrm{O}_{2} / \mathrm{UV}$ process. Within a very short span of the reaction, more than $98 \%$ of color and $36.8 \%$ of dissolved organic carbon were removed by the Fenton reagent. A reduction of $93,80,85$, and $88 \%$ of $\mathrm{BOD}$, COD, color, dissolved organic carbon respectively was observed when the photo-Fenton process was integrated with the biological system.

\section{Nano photocatalyst application in wastewater treatment}

The advanced oxidation processes (AOPs) have gained exceptional recognition concerning the advancement of wastewater treatment technologies for two decades. Some of the methods, including Fenton, cavitation, ozonation, and photocatalytic oxidation have been effectively utilized for the breakdown of recalcitrant organic contaminants at the pilot scale. Research has been done beforehand on both the homogenous and heterogeneous AOPs in the wastewater treatment domain. Catalysts such as $\mathrm{TiO}_{2}$, $\mathrm{ZnO}, \mathrm{UV} /$ visible light, various oxidants such as $\mathrm{H}_{2} \mathrm{O}_{2}$, $\mathrm{O}_{3}$, etc. are employed to stimulate AOPs. At the time of activation, AOPs produce ${ }^{\circ} \mathrm{OH}$ radicals and react with organic composites in the proximity of dissolved $\mathrm{O}_{2}$ of solvent media. Amid, several other industries, dyeing, printing, and paper industries are highly polluting the environment and this is because of the immense usage of the organic dyes in the course of the process. The absorption and reflection of the sunlight will be hindered because of the presence of organic dyestuffs in water bodies. Thus it results in an increase in noxious concentration which eventually troubles the aquatic life. Absolute mineralization of organic colorants can be achieved by employing dynamic AOPs. Several studies on different AOPs have 
Table 1 Application of advanced oxidation processes (AOPs) for the treatment of various textile effluents containing dyes

\begin{tabular}{|c|c|c|c|}
\hline Method & Wastewater & Results & References \\
\hline Heterogeneous Photocatalysis & $\begin{array}{l}\text { Remazol Brilliant Blue R, Red } \\
\text { Procion, Yellow Procion (EFA, } \\
\text { EFB, and EFC textile industry } \\
\text { effluents) }\end{array}$ & $\begin{array}{l}\text { More than } 90 \% \text { of COD removal was } \\
\text { achieved, and the } \mathrm{H}_{2} \mathrm{O}_{2} \text { added was } \\
\text { completely absorbed. At } 430 \mathrm{~nm}, 100 \text { and } \\
67.36 \% \text { of EFC and EFB effluents were } \\
\text { degraded. }\end{array}$ & $\begin{array}{c}\text { Garcia et al. } \\
\text { (2007) }\end{array}$ \\
\hline $\begin{array}{l}\text { Chemical treatment techniques } \\
\text { like } \mathrm{Fe}^{2+} / \mathrm{H}_{2} \mathrm{O}_{2}, \mathrm{H}_{2} \mathrm{O}_{2} / \mathrm{UV}, \mathrm{O}_{3}, \\
\text { etc. and advanced oxidation } \\
\text { processes }\end{array}$ & $\begin{array}{l}\text { Color and COD removal from } \\
\text { acetate and polyester fiber } \\
\text { dyeing effluent }\end{array}$ & $\begin{array}{l}\text { AOP results in } 60 \% \text { of COD and } 50 \% \text { of } \\
\text { color removal, while } 96 \% \text { of color and } \\
99 \% \text { of COD removal was achieved by } \\
\text { integrating the AOP with the } \mathrm{O}_{3} / \mathrm{H}_{2} \mathrm{O}_{2} / \\
\text { UV conventional method. }\end{array}$ & $\begin{array}{c}\text { Azbar et al. } \\
\text { (2004) }\end{array}$ \\
\hline $\begin{array}{l}\text { Advanced oxidation processes } \\
\text { (AOPs) }\end{array}$ & Cotton-textile dyeing wastewater & $\begin{array}{l}\text { At } 60 \mathrm{mg} \text { catalyst loading, } 85.5 \% \\
\text { mineralization, and } 98.5 \% \text { decolorization } \\
\text { was achieved in the solar-photo-Fenton } \\
\text { process. While, by integrating the } \\
\text { biological process with solar-photo- } \\
\text { Fenton reaction, } 0.5 \mathrm{kJUV} / \mathrm{L} \text { of photo } \\
\text { treatment energy and } 7.5 \mathrm{mM} \text { of } \mathrm{H}_{2} \mathrm{O}_{2} \text { is } \\
\text { required to attain the COD below } 250 \mathrm{mg} \\
\mathrm{O}_{2} / \mathrm{L} \text {. }\end{array}$ & $\begin{array}{l}\text { Soares et al. } \\
(2014)\end{array}$ \\
\hline $\begin{array}{l}\text { Advanced oxidation processes } \\
\left(\mathrm{H}_{2} \mathrm{O}_{2} / \mathrm{UV}, \mathrm{UV}, \mathrm{O}_{3}\right)\end{array}$ & Textile dye bath effluent & $\begin{array}{l}\text { On the application of } \mathrm{H}_{2} \mathrm{O}_{2} / \mathrm{UV} \text { on } \\
\text { biotreated dye bath effluent, } 98 \% \text { of } \\
\text { decolorization was achieved. Application } \\
\text { of AOPs following the biotreatment has } \\
\text { surpassed the biodegradability. }\end{array}$ & $\begin{array}{l}\text { Muhammad } \\
\text { et al. } \\
\text { (2008) }\end{array}$ \\
\hline
\end{tabular}

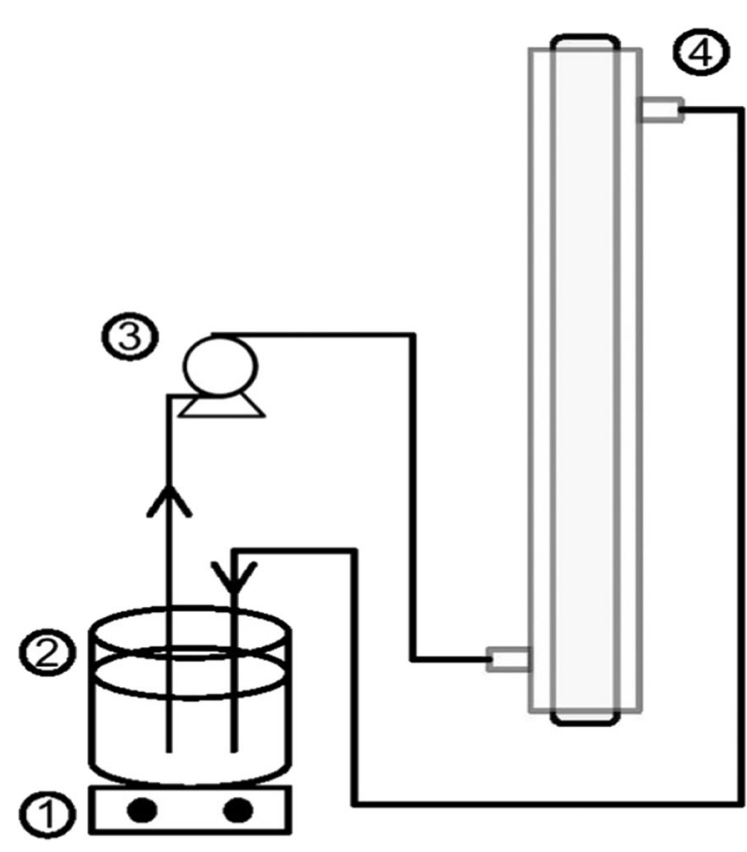

Fig. 1 System set-up for Reactive Blue 19 dye degradation by advanced oxidation processes, in which (1) a magnetic stirrer; (2) a reservoir of 9 L capacity; (3) a flow pump, and (4) a photoreactor (Reprinted from (Guimarães et al. 2012), Copyright (2012) with the permission from Elsevier) explained the successful breakdown of the dye contaminants in aqueous media. The photocatalytic AOP could commence the intricate chain reactions and there is also a chance of generation of uncolored organic intermediates and the generated intermediates sometimes become poisonous. Many previous studies have revealed that for the breakdown of the organic composites, microsize catalysts were used in different AOPs, but utilization of nanomaterials in AOPs for the wastewater treatment has not been reported (Geng et al. 2009; Chang et al. 2009). Some of the semiconductors like $\mathrm{TiO}_{2}, \mathrm{CdS}, \mathrm{ZnO}, \mathrm{WO}_{3}$ have been used as photocatalysts have been reported by Elamin and Elsanousi (2013). Among the photocatalytic materials, such as $\mathrm{ZnO}$ is considered one of the finest materials for the efficient breakdown of organic contaminants. Various studies have also revealed, that $\mathrm{ZnO}$ is highly photochemically reactive, economical and non-toxic and in terms of organic contaminants breakdown, as compared to $\mathrm{TiO}_{2}$ (Pardeshi and Patil 2009; Strunk et al. 2009; Ali et al. 2010; Huang et al. 2012; Danwittayakul et al. 2013, 2015). It would be advantageous if $\mathrm{ZnO}$ assimilates visible light apart from UV light and it will benefit in the enhancement of 
Table 2 Application of UV-visible induced nanomaterials as photocatalysts for the degradation of different organic contaminants in aqueous solutions

\begin{tabular}{|c|c|c|c|}
\hline Method & Wastewater & Results & References \\
\hline $\begin{array}{l}\text { Photocatalysis/Mn-doped } \\
\text { ZnO particles }\end{array}$ & $\begin{array}{l}\text { Methylene } \\
\text { Blue }\end{array}$ & $\begin{array}{l}\text { The experiments were conducted separately with Mn-doped } \mathrm{ZnO} \\
\text { particles and undoped } \mathrm{ZnO} \text { and observed that the doped particles } \\
\text { have degraded the } \mathrm{MB} \text { dye stuff more effectively and quickly than } \\
\text { the undoped particles. } 50 \% \text { of } \mathrm{MB} \text { dye was decolorized in } 5 \text { min } \\
\text { with } \mathrm{ZnO}: \mathrm{Mn}^{2+} \text { and UV. }\end{array}$ & $\begin{array}{l}\text { Ullah and } \\
\text { Dutta (2008) }\end{array}$ \\
\hline Photocatalysis/ZnO & $\begin{array}{l}\text { Basic Blue } \\
11(\mathrm{BB} \\
11)\end{array}$ & $\begin{array}{l}\text { It was observed that } \mathrm{N} \text { - hydroxy alkylated byproducts were } \\
\text { generated and } \mathrm{BB} 11 \text { dye has undergone oxidative breakdown } \\
\text { under UV irradiation, and }{ }^{\bullet} \mathrm{OH} \text { radical was major oxidant in this } \\
\text { process. It was observed that in } 24 \mathrm{~min}, 0.05 \mathrm{~g} / \mathrm{L} \text { of dye was } \\
\text { degraded to } 1 \% \text { approximately }\left[1-\left(\mathrm{C} / \mathrm{C}_{0}\right)\right]\end{array}$ & $\begin{array}{l}\text { Lu et al. } \\
\qquad(2009 a)\end{array}$ \\
\hline $\begin{array}{l}\text { Photocatalysis/Nd-doped } \\
\mathrm{TiO}_{2} \text { films }\end{array}$ & RhodaminB & $\begin{array}{l}\text { Photocatalytic action of the doped } \mathrm{TiO}_{2} \text { films was assessed under } \\
\text { UV light by employing the textile industry contaminant } \\
\text { Rhodamine } \mathrm{B}(\mathrm{RhB}) \text { and it was noticed that in } 30 \mathrm{~min} \text { of initial } \\
\text { time } 98 \% \text { of } \mathrm{RhB} \text { dye was removed. }\end{array}$ & $\begin{array}{l}\text { WU et al. } \\
\text { (2009) }\end{array}$ \\
\hline $\begin{array}{l}\text { Photocatalysis/ZnO/ZTO } \\
\text { composites }\end{array}$ & $\begin{array}{l}\text { Methyl } \\
\text { Orange } \\
\text { (MO) }\end{array}$ & $\begin{array}{l}\text { By employing porous-ceramic-supported catalysts (CZnO/10ZTO) } \\
\text { and under UV light irradiation 50\% of MO dye was degraded in } \\
1 \mathrm{~h} \text { and approximately } 95 \% \text { of dye was degraded in } 3 \mathrm{~h} \text {. The } \\
\text { photocatalytic activity was enhanced because of the ZTO islands, } \\
\text { that were formed on the } \mathrm{ZnO} \text { nanorods. }\end{array}$ & $\begin{array}{r}\text { Danwittayakul } \\
\text { et al. (2013) }\end{array}$ \\
\hline $\begin{array}{l}\text { Photocatalysis/ZnO/ZTO } \\
\text { composites }\end{array}$ & $\begin{array}{l}\text { Organic } \\
\text { dyes }\end{array}$ & $\begin{array}{l}\text { On irradiating the textile wastewater by sunlight, } 77 \% \text { of COD } \\
\text { removal and } 50 \% \text { of photocatalytic breakdown efficiency was } \\
\text { achieved by employing } \mathrm{ZnO} / 15 \mathrm{ZTO} \text { photocatalyst. The results } \\
\text { were promising when the } \mathrm{ZnO} / 15 \mathrm{ZTO} \text { catalyst was used under } \\
\text { solar light irradiation and about } 16 \% \text { degradation efficiency was } \\
\text { increased. Figure } 2 \text { explains the SEM and EDS results of } \mathrm{ZnO} / \\
\text { ZTO composite oxides with different compositions synthesized on } \\
\text { ZTO seeded substrate: (a) ZnO/5ZTO, (b) ZnO/10ZTO, (c) ZnO/ } \\
\text { 15ZTO }\end{array}$ & $\begin{array}{l}\text { Danwittayakul } \\
\text { et al. (2015) }\end{array}$ \\
\hline $\begin{array}{l}\text { Photocatalysis/synthesized } \\
\mathrm{ZnO}\end{array}$ & $\begin{array}{l}\text { Malachite } \\
\text { green } \\
\text { (MG) }\end{array}$ & $\begin{array}{l}\text { The photodegradation of malachite green (MG) dye was studied by } \\
\text { using } \mathrm{ZnO} \text { photocatalysts synthesized by various techniques. And } \\
\text { also, the impact of several operating conditions, including } \mathrm{pH} \text {, } \\
\text { catalyst loading, light source, and initial dye concentration on } \mathrm{MG} \\
\text { dye breakdown was analyzed. Under UV light, } 93.75 \% \text { of dye was } \\
\text { degraded. }\end{array}$ & $\begin{array}{l}\text { Saikia et al. } \\
\text { (2015) }\end{array}$ \\
\hline $\begin{array}{l}\text { Heterogeneous } \\
\text { photocatalysis/UV-C/TiO } \\
(\mathrm{PET}) / \mathrm{H}_{2} \mathrm{O}_{2}\end{array}$ & $\begin{array}{l}\text { Leaf green } \\
\text { dye }\end{array}$ & $\begin{array}{l}\text { The leaf green dye from the aqueous solution was removed by } \\
\text { employing } \mathrm{TiO}_{2} \text { photocatalyst immobilized on polyethylene } \\
\text { terephthalate (PET) plates and also in suspension form under UV } \\
\text { light irradiation. } 52 \% \text { of TOC and } 70 \% \text { of COD reduction was } \\
\text { achieved in UV-C/TiO } 2 \text { (PET) } / \mathrm{H}_{2} \mathrm{O}_{2} \text { system. }\end{array}$ & $\begin{array}{l}\text { Aquino et al. } \\
\text { (2019) }\end{array}$ \\
\hline
\end{tabular}

photocatalytic efficiency. Moreover, it is possible to absorb the visible light by bifurcating the $\mathrm{ZnO}$ bandgap into various sub gaps, and the bifurcation of $\mathrm{ZnO}$ can be attained by nitrogen doping (Elamin and Elsanousi 2013). Different researchers have reported, that since two decades the utilization of nanocrystalline $\mathrm{ZnO}$ and $\mathrm{TiO}_{2}$ as photocatalysts for the breakdown of organic contaminants has been largely improved (Moon et al. 2003; Suárez-Parra et al. 2003;
Yu et al. 2005; Peng et al. 2006b; Min et al. 2007; Venkatachalam et al. 2007; Wang et al. 2007; Pouretedal et al. 2009).

$$
\begin{aligned}
& \mathrm{OH}+\mathrm{h}^{+} \rightarrow \mathrm{OH} \\
& \mathrm{H}_{2} \mathrm{O}+\mathrm{h}^{+} \rightarrow \mathrm{OH}+\mathrm{H}^{+}
\end{aligned}
$$

About $70-80 \%$ of the literature in the wastewater treatment using photocatalysis and $\mathrm{ZnO} / \mathrm{TiO}_{2}$ as a photocatalyst is accessible and few researchers have 


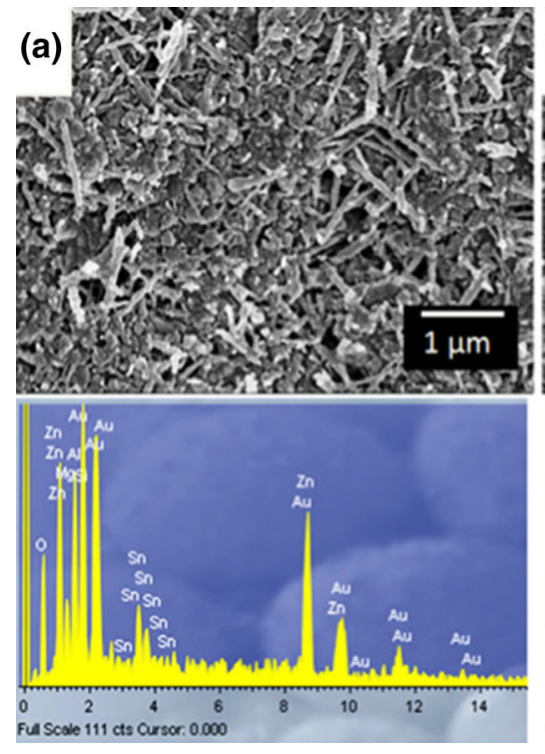

Fig. 2 SEM images and EDS results of ZnO/ZTO composite oxides with different compositions synthesized on ZTO seeded substrate: a $\mathrm{ZnO} / 5 \mathrm{ZTO}$, b $\mathrm{ZnO} / 10 \mathrm{ZTO}$, c $\mathrm{ZnO} / 15 \mathrm{ZTO}$

trialed the utilization of doped $\mathrm{TiO}_{2}$ for the pollutant degradation. $\mathrm{TiO}_{2}$ photocatalyst is called as semiconductor because it consists of a wide bandgap (3.2 eV) and parallel to radiation in the close UV range is beneficial compared to other photocatalysts. The $\mathrm{ZnO} /$ $\mathrm{TiO}_{2}$ particles get excited on UV light irradiation and produce a set of holes and electrons in the valence and conduction band. The charged species could relocate to the surface of the particle or they can combine with the dissolute heat from the absorbed energy and the holes to form hydroxyl radicals $(\mathrm{OH} \cdot)$ reacts with $\mathrm{OH}^{-}$ group and adsorbs $\mathrm{H}_{2} \mathrm{O}$ molecules.

To begin with the photocatalytic reaction wherein the organic contaminants breakdown in wastewater, both the light source and photocatalyst are mandatorily required. Recent studies have focused on the feasibility usage of visible light/sunlight for commencing the photocatalytic reaction and this will save a lot of energy, resources and also reduce the operating costs. Some of the recent studies on textile dye wastewater treatment using photocatalysis are discussed below in Table 2.

\section{Ceramic membrane filtration in wastewater treatment}

Recently, the ceramic membranes are gaining great attention, because of their superior characteristics like a long operating cycle, simple cleaning, regeneration, good chemical reliability, and pollution-free in the application of treatment of wastewater (Meabe et al. 2011). In the past, the ceramic membrane had limited application range, and was very expensive (Fujioka et al. 2014). But, later on, advancements in membrane research have resulted in the utilization of membrane technology for various purposes and have become cost-effective (Lee et al. 2015). Because of the fouling issue, the influent water standards are to be analyzed before the ceramic membrane is utilized in the industrial wastewater treatment process. In removing the pollutants from the wastewater the ceramic membrane follows two steps (Ali et al. 2017). All the particles that are enormous than the membrane size are blocked by the membrane, known as the selfretaining activity of the membrane. The smaller molecular weight particles will be absorbed by the membrane due to electrostatic forces, chemical bonds, and Vander Waals forces and this is known as the adsorption potential of the membrane (Zhao et al. 2018). Depending on the pore size, the membranes are 
Table 3 Application of ceramic membrane filtration for the treatment of different organic contaminants in aqueous solution

\begin{tabular}{|c|c|c|c|}
\hline Method & Wastewater & Results & References \\
\hline $\begin{array}{l}\text { Integrated flocculation, cross- } \\
\text { flow microfiltration, and } \\
\text { ceramic membranes }\end{array}$ & $\begin{array}{l}\text { Sulfur black, 2,3-acidic and } \\
\text { DSD acidic wastewaters }\end{array}$ & $\begin{array}{l}\text { The results have shown the decline of absorbency } \\
\text { of sulfur black, DSD acidic, } 2,3 \text {-acidic } \\
\text { wastewater, and CODcr. At } 0.1 \mathrm{MPa} \text { operating } \\
\text { pressure and } 1.0 \mu \mathrm{m} \text { ceramic membrane } 93.3 \text {, } \\
44.1 \text { and } 32.1 \% \text { of absorbancy was achieved for } \\
\text { sulfur black, 2,3-acidic wastewater, and DSD } \\
\text { acidic wastewaters respectively. }\end{array}$ & $\begin{array}{c}\text { Xu et al. } \\
(2002)\end{array}$ \\
\hline $\begin{array}{l}\text { Three materialistic ceramic } \\
\text { membranes of different } \\
\text { molecular weight cut-offs }\end{array}$ & Textile dye wastewater & $\begin{array}{l}\text { The experimental results have shown, increase in } \\
\text { permeate flux, a very little cake layer formation } \\
\text { on the membrane, and minimal flux removal. } \\
\text { Moreover, at the lowest cross-flow velocity, } \\
\text { higher conductivity retention coefficients, and } \\
\text { COD were acquired. The color and turbidity } \\
\text { rejections were observed between } 98 \% \text { and } 84 \% \\
\text { respectively. }\end{array}$ & $\begin{array}{l}\text { Barredo- } \\
\text { Damas } \\
\text { et al. } \\
\text { (2010) }\end{array}$ \\
\hline $\begin{array}{l}\text { Integrated ceramic membrane } \\
\text { and ultrafiltration }\end{array}$ & $\begin{array}{l}\text { Textile wastewaters containing } \\
\text { a reactive dye [Reactive } \\
\text { Black } 5 \text { (RB5)] and } \mathrm{NaCl}\end{array}$ & $\begin{array}{l}\text { Under high pressure, very minimal color removal } \\
\text { and maximum flux decline were observed from } \\
\text { the experimental results. The solutions having } \\
\text { exclusively RB5 were decolorized by more than } \\
70 \% \text { during filtration. On the addition of } \mathrm{NaCl} \text { to } \\
\text { the solution, minimal rejection of color and } \\
\text { maximum decline of flux was also observed. The } \\
\text { authors have mentioned that this could be due to } \\
\text { the repulsion-attraction phenomena and } \\
\text { membrane charge. It was also mentioned that the } \\
\text { performance of the ultrafiltration and the } \\
\text { membrane fouling effect was majorly influenced } \\
\text { by the electrostatic interactions between the } \\
\text { membrane materials and solute particles. }\end{array}$ & $\begin{array}{l}\text { Alventosa- } \\
\text { Delara } \\
\text { et al. } \\
(2014)\end{array}$ \\
\hline $\begin{array}{l}\text { Ceramic microfiltration } \\
\text { membrane (Manufactured } \\
\text { with mineral coal fly ash) }\end{array}$ & Textile dye effluents & $\begin{array}{l}\text { A significant decline in the color of } 90 \% \text { and } 75 \% \\
\text { of COD was observed. The researchers have } \\
\text { compared and contrasted the permeate flux } \\
\text { performance with a commercial membrane and } \\
\text { observed the similarity. }\end{array}$ & $\begin{array}{l}\text { Jedidi et al. } \\
\text { (2011) }\end{array}$ \\
\hline
\end{tabular}

divided into four types namely; microfiltration, ultrafiltration, nanofiltration, and reverse osmosis (Jepsen et al. 2018). Excluding RO, the other three different membranes are employed in industrial wastewater treatment applications (Van Geluwe et al. 2011). Based on the shape, ceramic membranes could be classified into four types namely such as singlechannel tubular, multi-channel tubular, flat, and hollow fiber membrane (Wang et al. 2018). In the wastewater treatment process, the hollow fiber membrane is mostly employed. The flat membrane is widely used in the water resources area and the tubular membrane is employed in solid-liquid separation (Wang et al. 2018). Few recent studies on textile dye wastewater treatment using ceramic membranes are discussed below in Table 3 .

Various investigators used ceramic membranes and revealed that they are alternative to polymer membranes and have extraordinary characteristics like physical, mechanical, lower cleaning frequency, thermal stability, longer lifetime, chemical resistance (Karnik et al. 2005; Dow et al. 2013; Muthukumaran and Baskaran 2014). Barredo-Damas et al. (2012) have treated textile mill effluents by tubular ceramic ultrafiltration membranes at various operating constraints like molecular weight cut-off, $\mathrm{pH}$, and transmembrane pressure. Figure 3 is showing the schematic illustration of the wastewater treatment plant. The mixed waste streams are propelled into a 


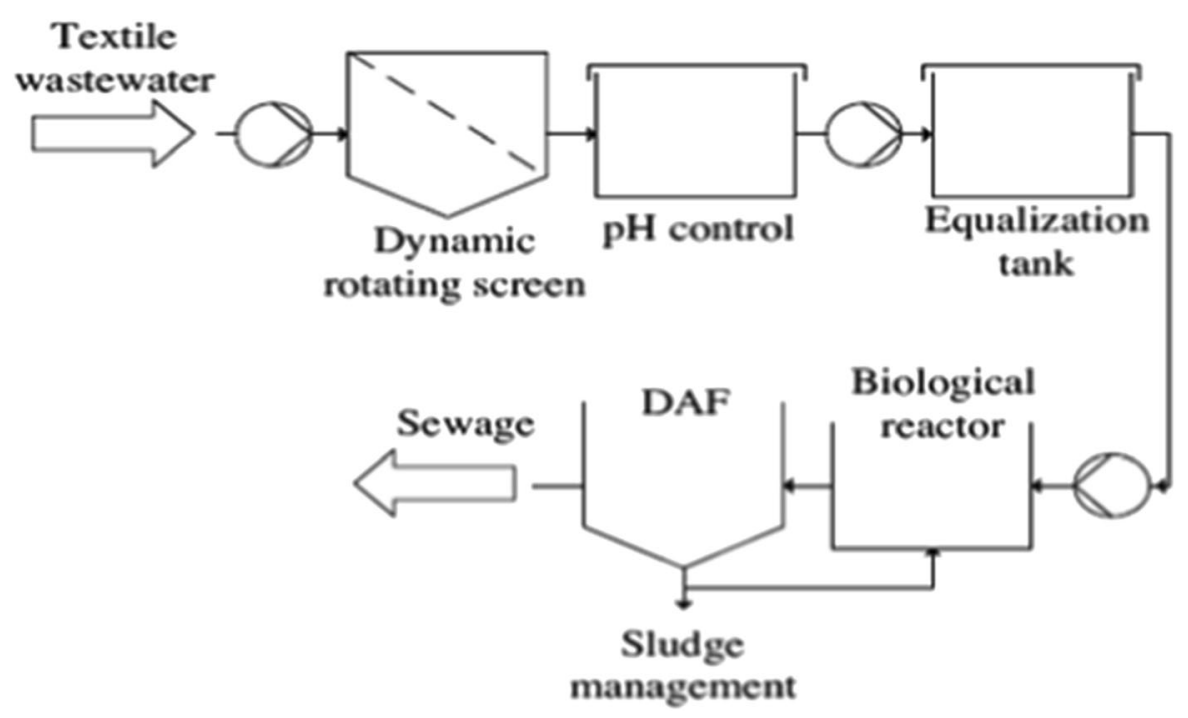

Fig. 3 Schematic illustration of the current wastewater treatment plant (Reprinted from (Barredo-Damas et al. 2012), Copyright (2012) with the permission from Elsevier)

dynamic rotating screen to remove bigger particles, then $\mathrm{pH}$ is regulated to 10.5 and sent to an equalization tank. Later, the solution is sent into a biological reactor, and to detach the activated sludge the effluent is driven into a dissolved air flotation tank (DAF). From the results, it has been observed that, for higher pressures, up to pseudo-stable values the permeate flux has been enhanced and $93 \%$ of turbidity, $96 \%$ of color, and $70 \%$ of COD removal have been observed from wastewater.

\section{Nanophotocatalysis coupled with ceramic membrane filtration for wastewater treatment}

The life span of the membrane decreases when the membrane undergoes fouling because of the precipitation or adsorption of molecules on its surface (Meng et al. 2009; Liu et al. 2010). The schematic illustration of the formation and removal of removable and irremovable fouling in MBRs was explained in Fig. 4. By applying physical cleaning, the removable fouling can be detached comfortably but chemical cleaning is required for irremovable fouling. Reversible fouling and removable fouling are similar. The reasons for the irremovable fouling and removable fouling are pore blocking and loosely attached foulants. This fouling complication is more conspicuous in ceramic and polymeric membranes. By integrating the photocatalytic system with membrane separation the fouling problem could be surpassed (Zhang et al. 2006a; Pidou et al. 2009). In the integrated hybrid system, because of the photocatalysis process, the ceramic membrane dismisses the suspended photocatalysts as well as the degraded the organic contaminants.

The hybrid method could be used as an application in the treatment of several wastewaters, breakdown of various organic contaminants, and also removal of dyes like methyl orange, direct black, congo red, methylene blue, etc. from textile dye wastewaters (Naresh Yadav et al. 2018). Several researchers have worked on the integrated hybrid system and the design and working conditions of each study are different from the other. In some research works, the membrane was submerged in the photocatalytic reactor, and in other studies, both the systems were combined sequentially ( $\mathrm{Li}$ et al. 2019; Donkadokula et al. 2020). Most of the researchers have utilized polymeric membranes for the combination with the photocatalytic process and very few researchers have used ceramic membranes in the integrated process (Song et al. 2018). Few recent studies on textile dye wastewater treatment using nanophotocatalysis coupled with ceramic membrane filtration are discussed below in Table 4.

The exotic materials like graphene oxide- $\mathrm{TiO}_{2}$ $\left(\mathrm{rGO} / \mathrm{TiO}_{2}\right)$ and altered $\mathrm{TiO}_{2}$ with an organic shell 

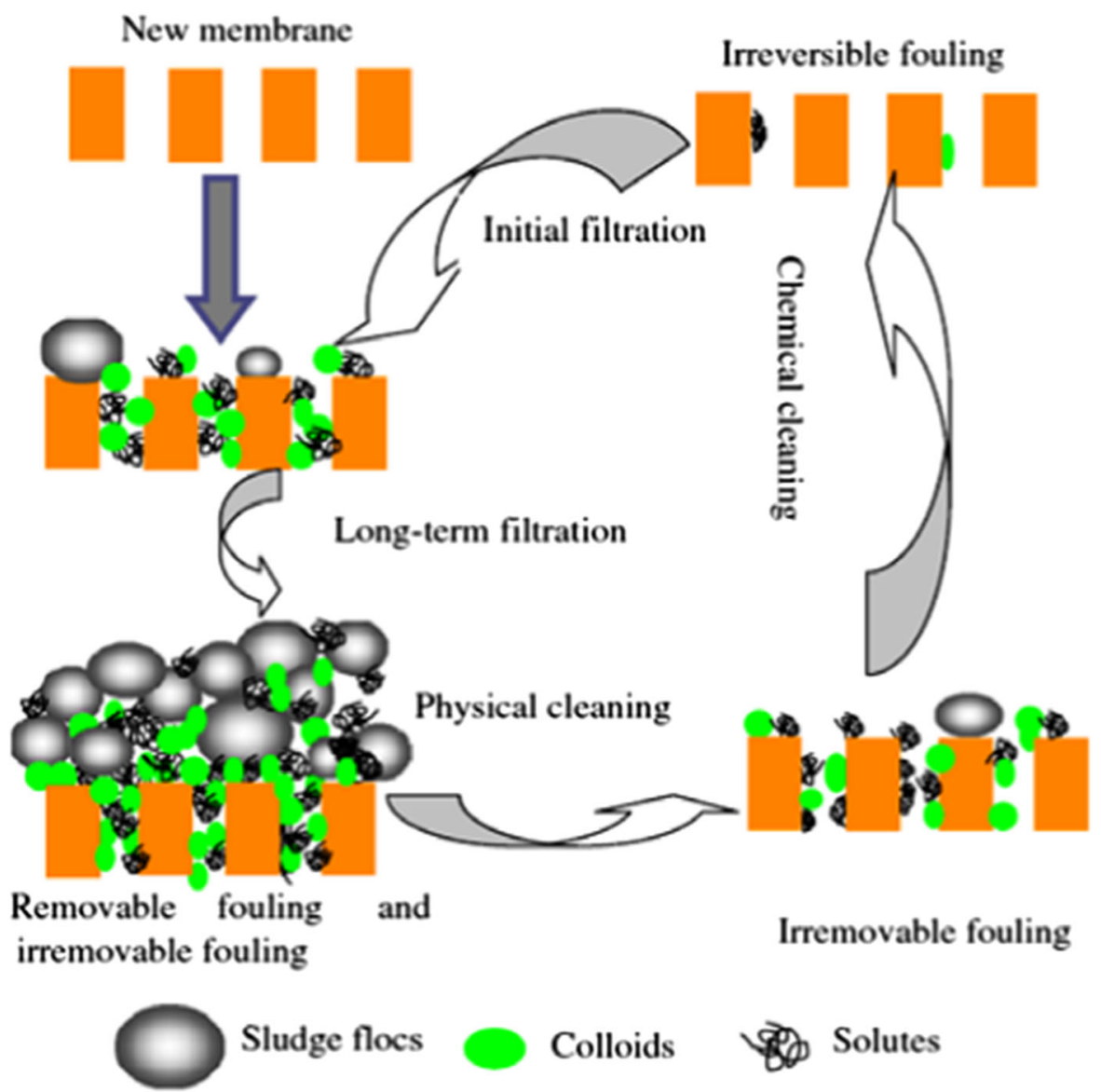

Fig. 4 Schematic illustration of the formation and removal of removable and irremovable fouling in MBRs (Reprinted from (Meng et al. 2009), Copyright (2009) with the permission from Elsevier)

layer was blended and fixed on the surface and pore structure of the monoliths (Athanasekou et al. 2013). They have studied the impact of various operating conditions including flow rate, feed concentration, and feed pressure on the membrane permeability and the efficiency of contaminants breakdown. Further, they have focused on the breakdown and removal of methyl orange (MO) and methylene blue (MB) under visible light irradiation and near-UV/Vis, and continuous flow photocatalytic filtration. From the results, it was observed that out of all the membranes, membrane $\mathrm{N}-\mathrm{TiO}_{2}-10$ has exhibited excessive $\mathrm{MB}$ dye removal efficiency i.e. 57\% under UV. Moreover, another research group investigated the photooxidation of organic pollutants present in the wastewater by using silica/titania nanotubes composite membranes. By utilizing porous alumina support membranes, the silica/titania membranes were formulated from silica/titania sols. The water contact angle has declined from $62^{\circ}$ to nearly $5^{\circ}$ in $80 \mathrm{~min}$ because of the surface membranes, which has shown an intense affinity for water under UV irradiation. For Direct Black 168 dye at $100 \mathrm{~min}$ of experimental operation, 73 and $66 \%$ of degradation were achieved in individual membrane separation and photocatalysis. Further, by integrating both the systems, i.e., the photocatalysis and the membrane separation process, $85 \%$ removal efficiency was achieved. From these results, it was concluded that the silica/titania nanotubes used in this study had multifunctions such as breakdown, refinement of membrane flux in photooxidation, and separation of organic pollutants in wastewater (Zhang et al. 2006b). Morover, Mozia (2010) explored the breakdown of toxic organic compounds in the presence of a photocatalytic membrane reactor using immobilized $\mathrm{TiO}_{2}$ particles onto the surface of polymeric 
Table 4 Application of nanophotocatalysis coupled with ceramic membrane filtration for the degradation of textile dyes

\begin{tabular}{|c|c|c|c|}
\hline Method & Wastewater & Results & References \\
\hline $\begin{array}{l}\text { Poly tetra fluoro ethylene (PTFE) } \\
\text { membrane module submerged in } \mathrm{TiO}_{2} \\
\text { slurry photocatalytic reactor }\end{array}$ & $\begin{array}{l}\text { Reactive } \\
\text { Black 5 } \\
\text { (RB5) }\end{array}$ & $\begin{array}{l}\text { At hydraulic retention time (HRT) of } 4 \mathrm{~h}, 45-93 \% \text { of } \\
\text { TOC, } 82-100 \% \text { of color and } 50-85 \% \text { of COD was } \\
\text { removed }\end{array}$ & $\begin{array}{l}\text { Damodar et al. } \\
\text { (2010) }\end{array}$ \\
\hline $\begin{array}{l}\text { Integrated microfiltration process with } \\
\text { heterogeneous photocatalytic system }\end{array}$ & $\begin{array}{l}\text { C.I. } \\
\text { Disperse } \\
\text { Red } 73\end{array}$ & $\begin{array}{l}60-90 \% \text { of dye degradation and } 98 \% \text { of COD removal } \\
\text { was achieved from the individual photocatalysis } \\
\text { system }\end{array}$ & $\begin{array}{l}\text { Buscio et al. } \\
\text { (2015) }\end{array}$ \\
\hline $\begin{array}{l}\text { Integrated photocatalytic membrane } \\
\text { reactor }\end{array}$ & $\begin{array}{l}\text { Congo red } \\
\text { dye }\end{array}$ & $\begin{array}{l}\text { By utilizing PVP (ZnO-PVP-St) under stirring } \\
\text { stipulations and in the absence of agglomerations } \\
\text { four kinds of Zinc Oxides were fused. At } 0.3 \mathrm{~g} / \mathrm{L} \\
\mathrm{ZnO}-\mathrm{PVP}-\mathrm{St} \text { loading } 65 \pm 1.0 \% \text { and } 100 \pm 0.5 \% \text { of } \\
\text { dye degradation was observed after photocatalysis } \\
\text { and nanofiltration respectively. The minimal } \\
\text { membrane flux removal and higher photodegradation } \\
\text { coherence in MPR were achieved due to the presence } \\
\text { of ZnO-PVP-St }\end{array}$ & $\begin{array}{l}\text { Hairom et al. } \\
\text { (2014) }\end{array}$ \\
\hline $\begin{array}{l}\text { Combined ceramic membrane system with } \\
\text { photocatalysis }\end{array}$ & $\begin{array}{l}\text { Methyl } \\
\text { Orange } \\
\text { (MO) }\end{array}$ & $\begin{array}{l}\text { The study has revealed that the integration of both } \\
\text { systems has numerous advantages especially in terms } \\
\text { of expenditure and compactness. From the obtained } \\
\text { experimental outcomes it was noticed that } 90.4 \% \text { and } \\
77 \% \text { of MO dye was degraded in the coupling and } \\
\text { cylindrical reactors respectively. }\end{array}$ & $\begin{array}{l}\text { Peng et al. } \\
\text { (2006a), Lee } \\
\text { et al. (2001) }\end{array}$ \\
\hline $\begin{array}{l}\text { Double-side active } \mathrm{TiO}_{2} \text {-modified } \\
\text { nanofiltration membranes in continuous } \\
\text { flow photocatalytic reactors }\end{array}$ & $\begin{array}{l}\text { Methyl } \\
\text { Orange } \\
\text { (MO) }\end{array}$ & $\begin{array}{l}\text { By employing UV irradiation on both sides of the } \\
\text { membrane, the efficiency of the membrane to } \\
\text { photodegrade distinctive water contaminants were } \\
\text { assessed. The results indicated that the high water } \\
\text { permeability and low adsorption-fouling propensity } \\
\text { were observed during the decomposition of methyl } \\
\text { orange in the composite NF membranes }\end{array}$ & $\begin{array}{l}\text { Romanos et al. } \\
\text { (2012) }\end{array}$ \\
\hline $\begin{array}{l}\text { Photocatalytic degradation combined with } \\
\mathrm{TiO}_{2} \text { membrane assisted on a porous } \\
\text { ceramic tube }\end{array}$ & Acid Red 4 & $\begin{array}{l}\text { The conclusions of this research work include; } \\
\text { (a) three and five times higher decomposition ratios } \\
\text { for the dead-end system than the cross-flow system, } \\
\text { (b) on enhancing catalyst loading and light intensity, } \\
\text { the decomposition ratio has enhanced, but at higher } \\
\text { catalyst loading it remained constant (c) and with } \\
\text { increasing flow rate the decomposition ratio declined }\end{array}$ & $\begin{array}{l}\text { Wang et al. } \\
\text { (2008) }\end{array}$ \\
\hline
\end{tabular}

membranes and their investigations showed that UV irradiation slightly damaged the polymeric membranes.

\section{Wastewater treatment using biofilms}

Among all biological methods, biofilm technologies play a vital role in the treatment of various wastewaters (Sehar and Naz 2016). Biofilms are composed of several microbial communities bounded in self-generated extracellular polymeric substance (EPS) matrices (Naresh Yadav et al. 2020). The biofilm development has five important phases; (1) The early attachment of planktonic microbes to a solid surface or with one another in an aqueous media; (2) Absolute fixation consequent to the generation of microorganism-moderated EPSs as polyhydroxyl groups and along hydrogen bonding these polyhydroxyl groups seize bacteria to the surface (van Belkum 2007); (3) Development of monolayer mini colonies on the firm surface as attached growth or suspended growth because of the replication of initial colonizers; (4) Biofilm development into 3D form by utilizing the new planktonic bacteria and also by binding the detritus from the adjoining surroundings, and (5) diversification or scattering by passive and active methods in which the matrix-encased biofilm cells 
Table 5 Application of biofilm processes for textile dye wastewater treatment

\begin{tabular}{|c|c|c|c|}
\hline Method & Wastewater & Results & References \\
\hline $\begin{array}{l}\text { Anaerobic biofilm method combined with photo- } \\
\text { Fenton oxidation }\end{array}$ & $\begin{array}{l}\text { Textile azo } \\
\text { dyes } \\
\text { (Remazol } \\
\text { Red) }\end{array}$ & $\begin{array}{l}\text { On using the primary Fenton reagent concentration } \\
\text { less than } 10 \mathrm{mM} \mathrm{H}_{2} \mathrm{O}_{2} \text { and } 1 \mathrm{mM} \text { ferrous ions, } \\
\text { COD was diminished to lower than } 18 \mathrm{mg} / \mathrm{l} \text {. } \\
\text { Eventually, the toxicity was also reduced by the } \\
\text { photo-Fenton oxidation, but the final effluent } \\
\text { consisted of high concentrated } \mathrm{NaCl} \text {. More than } \\
90 \% \text { of absorbance and COD removal were } \\
\text { observed in this study. The obtained } \\
\text { experimental outcomes of this research work } \\
\text { have recommended the utilization of photo } \\
\text { Fenton oxidation after biological treatment for } \\
\text { the elimination of toxic and organic pollutants } \\
\text { from the textile effluents }\end{array}$ & $\begin{array}{l}\text { Punzi } \\
\text { et al. } \\
(2015)\end{array}$ \\
\hline Three-stage moving-bed biofilm reactor & $\begin{array}{l}\text { Textile dye } \\
\text { wastewater }\end{array}$ & $\begin{array}{l}\text { For the biological treatment, polyurethane- } \\
\text { activated carbon (PU-AC) }(20 \% \text { v/v) was filled } \\
\text { in each reactor and the activated sludge was } \\
\text { inoculated into MBBRs. At HRT } 44 \mathrm{~h}, 50 \% \text { of } \\
\text { color and } 86 \% \text { of COD was removed by the } \\
\text { MBBR process and this was the significant } \\
\text { results for the treatment of dye wastewater }\end{array}$ & $\begin{array}{l}\text { Park et al. } \\
\text { (2010) }\end{array}$ \\
\hline $\begin{array}{l}\text { Dye-degrading bacterial strains such as } \\
\text { Lysinibacillus fusiformis strain } Z B 2 \text {, } \\
\text { Brevibacillus panacihumi strain } Z B 1 \text {, Bacillus } \\
\text { cereus strain } Z K 2 \text {, and Bacillus pumilus strain } \\
Z K 1\end{array}$ & $\begin{array}{l}\text { Textile } \\
\text { wastewater }\end{array}$ & $\begin{array}{l}\text { The researchers in this study have used sterile } \\
\text { sludge as a seeding agent. From the experimental } \\
\text { results it was observed that at HRT of } 24 \mathrm{~h}, 46 \% \\
\text { of COD and } 61 \% \text { of color removal was achieved } \\
\text { by the developed granules. The results have } \\
\text { revealed that for efficient textile wastewater } \\
\text { treatment such as bacterial mixed cultures are } \\
\text { highly promising }\end{array}$ & $\begin{array}{l}\text { Kee et al. } \\
\quad(2015)\end{array}$ \\
\hline
\end{tabular}

transform into planktonic bacteria through a cell-tocell signaling procedure (Webb 2009; Paridah et al. 2016). Factors that affect the formation of biofilm are nutrients, $\mathrm{pH}$, temperature, the surface topology of support media, velocity, turbulence, hydrodynamics, production of EPS, and divalent cations (Ansari et al. 2017; Krivorot et al. 2011). To allocate the attachment surfaces for biofilm development, the Solid Support Media (SSM) is incorporated in the suspended growth reactors. The addition of SSM enhances the microbial concentration and breakdown the pollutants as well (Pal et al. 2010). The carbonaceous materials, phosphorous, trapped pathogens, nitrogen-containing compounds, and nutrients from the wastewater are degraded by the various microbial populations present in the biofilm matrix. Advantages offered by the biofilm-based wastewater treatment plants are flexibility in operation, less space required, decrease in hydraulic retention time, the less effective over the environment, increase in biomass weight, low sludge production, superior biomass residence time, and superior capability to degrade complex compounds (Martin and Nerenberg 2012; Lewandowski and Boltz 2010). Few recent studies on textile dye wastewater treatment using biofilms are discussed below in Table 5.

Ong et al. (2008) by employing the Granular activated carbon-biofilm configured sequencing batch reactor evaluated the C.I. Acid Orange 7 (AO7) mineralization. The schematic illustration of the granular activated carbon-biofilm configured sequencing batch carbon reactor (SBCR) was shown in Fig. 5 . The dimensions of the SBCR was $20 \times 20 \times 20 \mathrm{~cm}$ and was split into two sections, specifically Multipurpose (MP) and GAC compartments. Granular activated carbon (2.3 l) was used to fill the GAC compartment and using an attachment the azo dye degrading microorganisms were attenuated on GAC. To restraint the DO and to maintain efficacious mixing a mixer was established in the MP compartment. To 


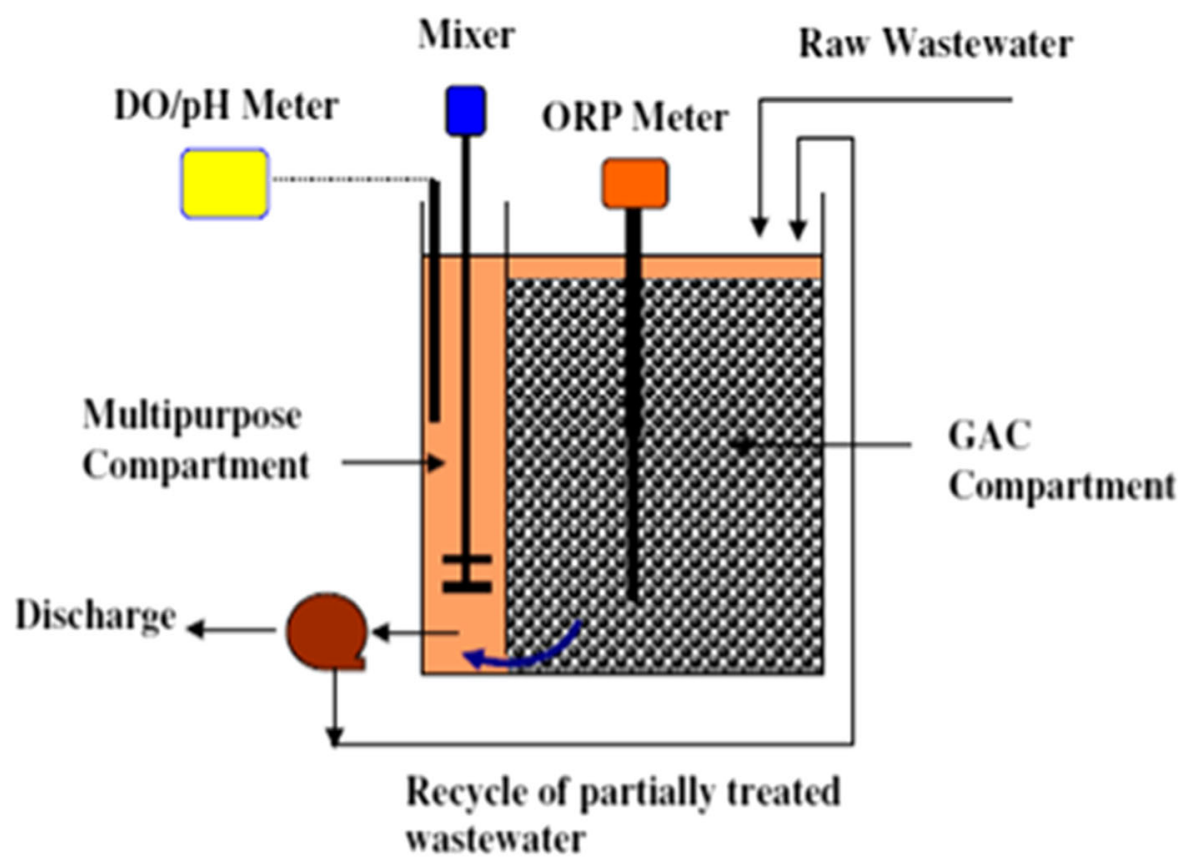

Fig. 5 Schematic diagram of granular activated carbon-biofilm configured sequencing batch carbon reactor (SBCR) (Reprinted from (Ong et al. 2008), Copyright (2006) with the permission from Elsevier)

observe the ORP values and the $\mathrm{pH}$, a redox meter and a $\mathrm{pH}$ meter were kept in GAC and MP compartments respectively. By submerging the GAC into the anaerobic bioreactor, it was disabled with microbes that degrade the azo dyes. Wastewater containing 21 of AO7 was fed into SBCR and operated for $24 \mathrm{~h}$ cycle time in the ratio of 3:20:0.45:0.15. At $625 \mathrm{mg} / \mathrm{L}$ of initial AO7 concentration, less than $0.25 \mathrm{mg} / \mathrm{L} \mathrm{DO}$, and in the absence of outside carbon sources, the biological system has achieved almost absolute mineralization of $\mathrm{AO} 7$.

\section{Combination of advanced chemical and biological processes}

Major chemical pollutants like pesticides, dyes, solvents, heavy metals, etc. are considered hazardous materials and major threats to the purity of water (Rasalingam et al. 2014). Through wastewater treatment plants or in other ways the chemicals penetrate the aquatic medium and substantial amounts of tenacious substances will be spread over to very long distances from the pollutant's source point. Photodegradation and biodegradation are considered as the most suitable methods for demolishing the noxious compounds in natural water. Pesticides, phenols, aromatic hydrocarbons, etc. can be degraded by using photodegradation (Van Leeuwen 1996). And in the biodegradation method, generally by using the microbes, the pollutants are eliminated. Studies have revealed that the integration of biological methods with the chemical oxidation processes will enhance the efficiency and lower the operating costs (Oller et al. 2011). Few recent studies on textile dye wastewater treatment using combined advanced chemical and biological processes are discussed below in Table 6.

Rodrigues et al. (2014) worked on the combined Fenton's process and a sequening batch reactor (SBR) for the removal of organic matter and color from polyester, cotton, and acrylic dye wastewaters. To minimize the operating costs and maximize the DOC and color removal, the $\mathrm{H}_{2} \mathrm{O}_{2}$ and $\mathrm{Fe}$ (II) were applied in optimum dosage in the combined process. The installation framework was demonstrated in Fig. 6. At persistent temperature $\left(25^{\circ} \mathrm{C}\right)$ the biological reactor was operated till 10 cycles ( $12 \mathrm{~h} /$ cycle). After adjusting the $\mathrm{pH}$ to 7.0 in the first cycle, the biological reactor was supplemented with $2.5 \mathrm{~L}$ of wastewater. 
Table 6 Application of combined advanced chemical and biological processes for textile dye wastewater treatment

\begin{tabular}{|c|c|c|c|}
\hline Method & Wastewater & Results & References \\
\hline $\begin{array}{l}\text { Integrated chemical and biological } \\
\text { process }\end{array}$ & $\begin{array}{l}\text { Textile } \\
\text { Reactive azo } \\
\text { dye }\end{array}$ & $\begin{array}{l}\text { The integrated biological processes }(C \text {. oleophila }) \text { and } \\
\text { Fenton's process has decolorized } 91 \% \text { of RB5 dye having an } \\
\text { initial concentration of } 500 \mathrm{mg} / \mathrm{L}\end{array}$ & $\begin{array}{l}\text { Lucas } \\
\text { et al. } \\
\text { (2007) }\end{array}$ \\
\hline $\begin{array}{l}\text { Integrated biological biofilm and } \\
\text { ozonation }\end{array}$ & $\begin{array}{l}\text { Remazol Black } \\
\text { B }\end{array}$ & $\begin{array}{l}\text { The ozonation process acts as the pretreatment for dye } \\
\text { degradation. At } 500 \mathrm{mg} / \mathrm{L} \text { of Remazol Black B dye and } \mathrm{pH} \\
\text { 3-11, about } 96 \% \text { of dye removal was achieved. For the } \\
\text { biological treatment, the dye removal has increased with an } \\
\text { increase in ozonation time }\end{array}$ & $\begin{array}{l}\text { de Souza } \\
\text { et al. } \\
(2010)\end{array}$ \\
\hline $\begin{array}{l}\text { Combined up-flow biological } \\
\text { aerated filter and sequential } \\
\text { ozonation process }\end{array}$ & $\begin{array}{l}\text { Brilliant red } \\
\text { X-3B azo dye }\end{array}$ & $\begin{array}{l}\text { The ozonation was used as a pretreatment method in which } \\
\text { BOD }_{5} / \text { COD has enhanced from } 0.1 \text { to } 0.4 \text {, and in the } \\
\text { combined system around } 90 \% \text { of COD removal and } 97 \% \text { of } \\
\text { decolorization were achieved }\end{array}$ & $\begin{array}{l}\text { Lu et al. } \\
(2009 \mathrm{c})\end{array}$ \\
\hline $\begin{array}{l}\text { Combined sub-filtration and } \\
\text { biological process }\end{array}$ & $\begin{array}{l}\text { Dyeing and } \\
\text { printing } \\
\text { wastewaters }\end{array}$ & $\begin{array}{l}\text { The wastewater was initially treated by the biological process } \\
\text { and followed by a sub-filter method, and } 90.9,92.5 \text {, and } \\
91 \% \text { of average turbidity, color, and CODcr respectively } \\
\text { were achieved }\end{array}$ & $\begin{array}{l}\text { Lu et al. } \\
\text { (2009b) }\end{array}$ \\
\hline $\begin{array}{l}\text { Providencia sp. SDS (PS) and } \\
\text { Pseudomonas aeuroginosa strain } \\
\text { BCH (PA) }\end{array}$ & Red HE3B & $\begin{array}{l}\text { The degradation and decolorization of the Red HE3B by the } \\
\text { bacterial consortium (PS \& PA) found to be quicker than the } \\
\text { independent bacterial strain. Further, during degradation and } \\
\text { decolorization process several important dye decolorizing } \\
\text { enzymes (DCIP reductase, azoreductase, laccase, veratryl } \\
\text { alcohol oxidase) were inducted and it was found that in a } 1 \mathrm{~h} \\
\text { and at } 50 \mathrm{mg} / \mathrm{L} \text { dye concentration } 100 \% \text { decolorization was } \\
\text { achieved }\end{array}$ & $\begin{array}{l}\text { Phugare } \\
\text { et al. } \\
(2011)\end{array}$ \\
\hline Sphingobacterium sp. ATM & $\begin{array}{l}\text { Direct Blue } \\
\text { GLL } \\
\text { (DBGLL) }\end{array}$ & $\begin{array}{l}\text { 100\% of DBGLL ( } 300 \mathrm{mg} / \mathrm{L}) \text { dye was decolorized by } \\
\text { Sphingobacterium sp. ATM strain in } 24 \mathrm{~h} \text {. Few other textile } \\
\text { effluents and mixed dye effluents were also decolorized by } \\
\text { the same strain. At the time of DBGLL and other dyes } \\
\text { decolorization process, few enzymes (azo reductase, } \\
\text { riboflavin reductase, DCIP reductase, laccase, veratryl } \\
\text { alcohol oxidase) accountable of degradation were identified }\end{array}$ & $\begin{array}{l}\text { Tamboli } \\
\text { et al. } \\
(2010)\end{array}$ \\
\hline
\end{tabular}

The final volume was made to $5 \mathrm{~L}$ by adding $2.5 \mathrm{~L}$ of activated sludge. To reimburse the quantity of treated effluent released, the reactor was supplemented with $2.5 \mathrm{~L}$ of effluent. Using air diffusers, the DO content was enabled at $3 \pm 1.3 \mathrm{mg} \mathrm{O}_{2} / \mathrm{L}$ and a mechanical stirrer was utilized in the course of reaction stage. The oxidation-reduction potential (ORP), temperature, and $\mathrm{pH}$ were frequently observed. Dissolved organic carbon (DOC), COD, $\mathrm{BOD}_{5}$ and TSS were determined at the end of each cycle. Lab view 5.0 software was used to attain automatic unit control and data acquisition. The combined system has shown significant results than individual systems and has shown $99 \%$ of color, $91-98 \%$ of DOC, $83-95 \%$ of BOD, and $88-98 \%$ of COD removal. Further, 24-39\% of operating costs were reduced by the combined system. In a study, Shah et al. (2012) investigated the enzymatic degradation of Reactive Orange 13 dye using newly isolated bacterial strain Alcaligenes faecalis PMS-1. The experimental results have revealed that at static anoxic condition, $24.75 \mathrm{mg} / \mathrm{L} / \mathrm{h}$ average decolorization was achieved; which is 38.13 times higher than the existing literature results. By using MichaelisMenten kinetics, the Michaelis constant $\left(\mathrm{K}_{\mathrm{m}}\right)$ and the maximum rate $\left(\mathrm{V}_{\max }\right)$ were found to be $27.1 \mathrm{mg} / \mathrm{L} / \mathrm{h}$ and $105 \mathrm{mg} / \mathrm{L}$. At the time of RO 13 decolorization, NADH-DCIP reductase, Tyrosinase, Veratryl Alcohol Oxidase enzymes were noticed.

\section{Conclusions}

An enormous quantity of water is consumed by the textile industries which release a large amount of 


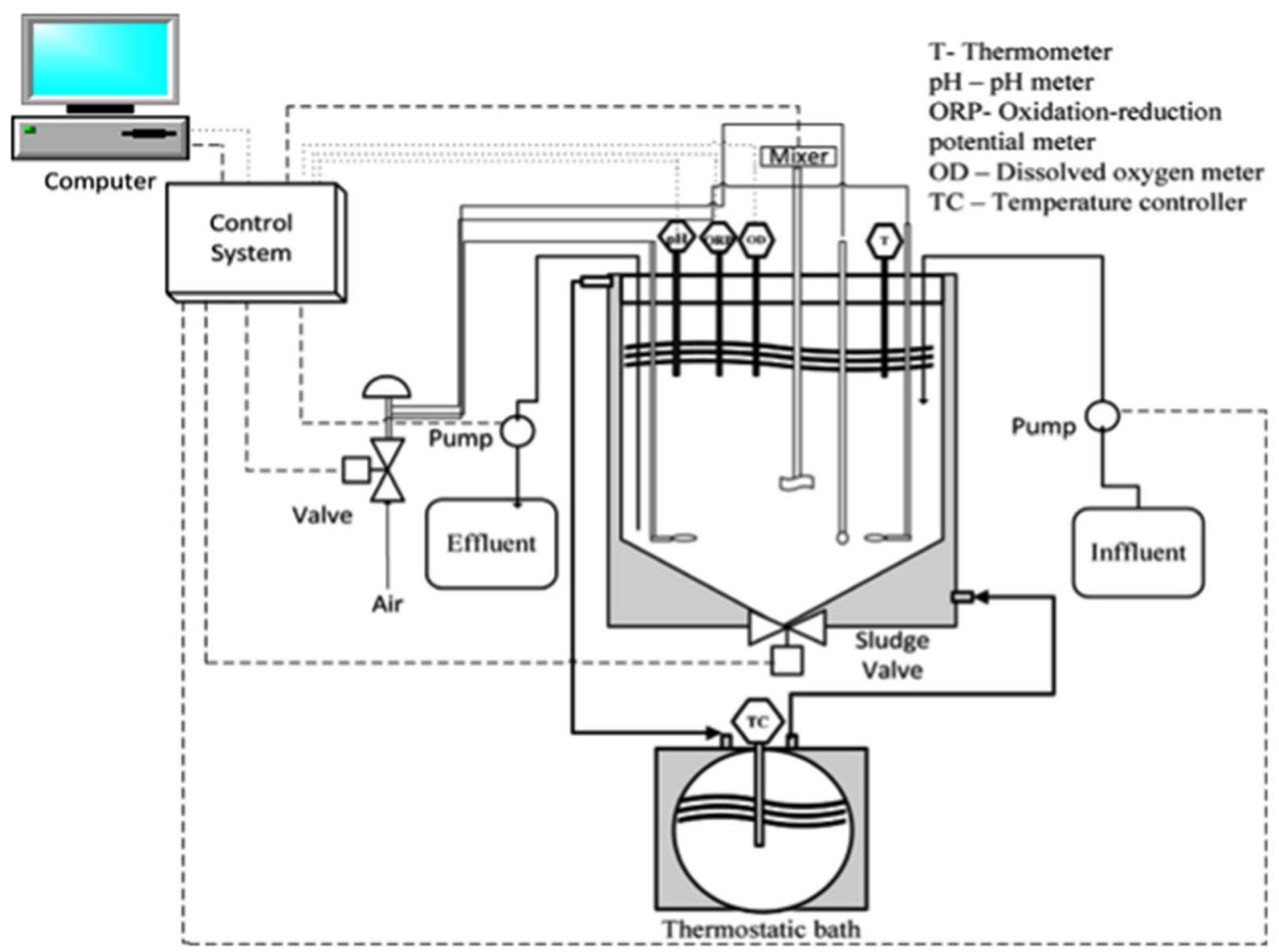

Fig. 6 Scematic illustration of a Sequencing Batch Reactor (SBR) set-up for textile effluent (Reprinted from (Rodrigues et al. 2014), Copyright (2014) with the permission from Elsevier)

wastewater having organic and inorganic pollutants. To protect the environment from these organic pollutants and to reuse the used water, the effluents are to be treated mandatorily in most places around the world. This short review concludes that various technologies (advanced Physico-chemical and biological) discussed here could be effectively employed in treating textile dye wastewaters. Various wastewater treatment methods are needed to be integrated into the streamlined treatment of contaminated water and also to reach the discharge standard. The techniques considered in the current review are the best befitting options for progressing wastewater at a small scale and also for real industrial wastewater treatment at a large scale. In the present scenario, these treatment methods are stimulating an important level of interest by environmental organizers. Because of potentially longer lifecycles, ease of maintenance, low capital costs, and capability to treat several organic contaminants in wastewater, these methods are considered as expedient. However, only a few studies have discussed treatment costs and the best available technology not entailing excessive cost becomes arduous when there are no-cost figures. Researchers in the coming future should concentrate on cost analysis of the treatment techniques and also on the treatment of complex and single dyes. In this paper, we have critically reviewed and examined the recent developments and progress in the application of photocatalytic materials and biofilms options for advanced textile dye wastewater treatment.

Acknowledgements The authors are grateful for the MHRD, Government of India, the Director, National Institute of Technology Warangal, and the University of Surrey, UK for the support during the research. The first author was supported 
by Newton Fund (British Council) $\mathrm{PhD}$ placement programme (Grant ID: 345740936).

\section{Compliance with ethical standards}

Conflict of interest The authors declare that there is no conflict of interest.

Open Access This article is licensed under a Creative Commons Attribution 4.0 International License, which permits use, sharing, adaptation, distribution and reproduction in any medium or format, as long as you give appropriate credit to the original author(s) and the source, provide a link to the Creative Commons licence, and indicate if changes were made. The images or other third party material in this article are included in the article's Creative Commons licence, unless indicated otherwise in a credit line to the material. If material is not included in the article's Creative Commons licence and your intended use is not permitted by statutory regulation or exceeds the permitted use, you will need to obtain permission directly from the copyright holder. To view a copy of this licence, visit http://creativecommons.org/licenses/by/4.0/.

\section{References}

Akpan UG, Hameed BH (2009) Parameters affecting the photocatalytic degradation of dyes using $\mathrm{TiO}_{2}$-based photocatalysts: a review. J Hazard Mater 170:520-529. https:// doi.org/10.1016/j.jhazmat.2009.05.039

Ali AM, Emanuelsson EAC, Patterson DA (2010) Photocatalysis with nanostructured zinc oxide thin films: the relationship between morphology and photocatalytic activity under oxygen limited and oxygen rich conditions and evidence for a Mars Van Krevelen mechanism. Appl Catal B Environ 97:168-181. https://doi.org/10.1016/j.apcatb. 2010.03.037

Ali A, Ahmed A, Gad A (2017) Chemical and microstructural analyses for heavy metals removal from water media by ceramic membrane filtration. Water Sci Technol 75:439-450. https://doi.org/10.2166/wst.2016.537

Alventosa-Delara E, Barredo-Damas S, Zuriaga-Agustí E et al (2014) Ultrafiltration ceramic membrane performance during the treatment of model solutions containing dye and salt. Sep Purif Technol 129:96-105. https://doi.org/10. 1016/j.seppur.2014.04.001

Ananthashankar R, Ghaly A (2013) Production, characterization and treatment of textile effluents: a critical review. J Chem Eng Process Technol 05:1-18. https://doi.org/10.4172/ 2157-7048.1000182

Ansari FA, Jafri H, Ahmad I, Abulreesh HH (2017) Factors Affecting Biofilm Formation in in vitro and in the Rhizosphere. Biofilms Plant Soil Heal. https://doi.org/10.1002/ 9781119246329.ch15

Aquino RVS, Barbosa AA, Ribeiro LB et al (2019) Degradation of leaf green food dye by heterogeneous photocatalysis with $\mathrm{TiO}_{2}$ over a polyethylene terephthalate plate. Chem Pap. https://doi.org/10.1007/s11696-019-00804-y

Athanasekou CP, Moustakas NG, Katsaros FK, et al (2013) Ceramic membranes in hybrid photocatalysis/ultrafiltration processes. In: Proceedings of 13th international conference environment science technology, 0319:5-7

Azbar N, Yonar T, Kestioglu K (2004) Comparison of various advanced oxidation processes and chemical treatment methods for COD and color removal from a polyester and acetate fiber dyeing effluent. Chemosphere 55:35-43. https://doi.org/10.1016/j.chemosphere.2003.10.046

Barredo-Damas S, Alcaina-Miranda MI, Bes-Piá A et al (2010) Ceramic membrane behavior in textile wastewater ultrafiltration. Desalination 250:623-628. https://doi.org/10. 1016/j.desal.2009.09.037

Barredo-Damas S, Alcaina-Miranda MI, Iborra-Clar MI, Mendoza-Roca JA (2012) Application of tubular ceramic ultrafiltration membranes for the treatment of integrated textile wastewaters. Chem Eng J 192:211-218. https://doi. org/10.1016/j.cej.2012.03.079

Buscio V, Brosillon S, Mendret J et al (2015) Photocatalytic membrane reactor for the removal of C.I. disperse red 73 . Materials (Basel) 8:3633-3647. https://doi.org/10.3390/ ma8063633

Chang JH, Yang TJ, Tung CH (2009) Performance of nano- and nonnano-catalytic electrodes for decontaminating municipal wastewater. J Hazard Mater 163:152-157. https://doi. org/10.1016/j.jhazmat.2008.06.072

Crini G (2006) Non-conventional low-cost adsorbents for dye removal: a review. Bioresour Technol 97:1061-1085. https://doi.org/10.1016/j.biortech.2005.05.001

Damodar RA, You SJ, Ou SH (2010) Coupling of membrane separation with photocatalytic slurry reactor for advanced dye wastewater treatment. Sep Purif Technol 76:64-71. https://doi.org/10.1016/j.seppur.2010.09.021

Danwittayakul S, Jaisai M, Koottatep T, Dutta J (2013) Enhancement of photocatalytic degradation of methyl orange by supported zinc oxide nanorods/zinc stannate (ZnO/ZTO) on porous substrates. Ind Eng Chem Res 52:13629-13636. https://doi.org/10.1021/ie4019726

Danwittayakul S, Jaisai M, Dutta J (2015) Efficient solar photocatalytic degradation of textile wastewater using $\mathrm{ZnO} /$ ZTO composites. Appl Catal B Environ 163:1-8. https:// doi.org/10.1016/j.apcatb.2014.07.042

de Souza SMADGU, Bonilla KAS, de Souza AAU (2010) Removal of COD and color from hydrolyzed textile azo dye by combined ozonation and biological treatment. J Hazard Mater 179:35-42. https://doi.org/10.1016/j. jhazmat.2010.02.053

Deng Y, Zhao R (2015) Advanced oxidation processes (AOPs) in wastewater treatment. Curr Pollut Reports 1:167-176. https://doi.org/10.1007/s40726-015-0015-z

Donkadokula NY, Kola AK, Saroj D (2020) Modelling and optimization studies on decolorization of brilliant green dye using integrated nanofiltration and photocatalysis. Sustain Environ Res 30:9. https://doi.org/10.1186/s42834020-00050-y

dos Santos AB, Cervantes FJ, van Lier JB (2007) Review paper on current technologies for decolourisation of textile wastewaters: perspectives for anaerobic biotechnology. Bioresour Technol 98:2369-2385. https://doi.org/10.1016/ j.biortech.2006.11.013

Dow N, Murphy D, Clement J, Duke M (2013) Outcomes of the Australian ozone/ceramic membrane trial on secondary effluent. Water J Aust Water Assoc 40:45-51 
Elamin N, Elsanousi A (2013) Synthesis of ZnO nanostructures and their photocatalytic activity. J Appl Ind Sci 1:32-35

Fallis A (2007) Advanced methods for treatment of textile industry effluents. J Chem Inf Model 53:1689-1699. https://doi.org/10.1017/CBO9781107415324.004

Fujioka T, Khan SJ, McDonald JA, Nghiem LD (2014) Nanofiltration of trace organic chemicals: a comparison between ceramic and polymeric membranes. Sep Purif Technol 136:258-264. https://doi.org/10.1016/j.seppur. 2014.08.039

Garcia JC, Oliveira JL, Silva AEC et al (2007) Comparative study of the degradation of real textile effluents by photocatalytic reactions involving $\mathrm{UV} / \mathrm{TiO} 2 / \mathrm{H}_{2} \mathrm{O}_{2}$ and $\mathrm{UV} /$ $\mathrm{Fe}_{2}+/ \mathrm{H}_{2} \mathrm{O}_{2}$ systems. J Hazard Mater 147:105-110. https://doi.org/10.1016/j.jhazmat.2006.12.053

Geng B, Jin Z, Li T, Qi X (2009) Kinetics of hexavalent chromium removal from water by chitosan-Fe0 nanoparticles. Chemosphere 75:825-830. https://doi.org/10.1016/j. chemosphere.2009.01.009

Guimarães JR, Guedes Maniero M, Nogueira de Araújo R (2012) A comparative study on the degradation of RB-19 dye in an aqueous medium by advanced oxidation processes. J Environ Manag 110:33-39. https://doi.org/10. 1016/j.jenvman.2012.05.020

Hairom NHH, Mohammad AW, Kadhum AAH (2014) Effect of various zinc oxide nanoparticles in membrane photocatalytic reactor for Congo red dye treatment. Sep Purif Technol 137:74-81. https://doi.org/10.1016/j.seppur.2014. 09.027

Holkar CR, Jadhav AJ, Pinjari DV et al (2016) A critical review on textile wastewater treatments: possible approaches. J Environ Manag 182:351-366. https://doi.org/10.1016/j. jenvman.2016.07.090

Huang J, Xu X, Gu C et al (2012) Effective VOCs gas sensor based on porous $\mathrm{SnO} 2$ microcubes prepared via spontaneous phase segregation. Sens Actuators B Chem 173:599-606. https://doi.org/10.1016/j.snb.2012.07.068

Hussein FH (2013) Chemical properties of treated textile dyeing wastewater. Asian J Chem 25:9393-9400. https://doi.org/ 10.14233/ajchem.2013.15909A

Jedidi I, Khemakhem S, Saïdi S et al (2011) Preparation of a new ceramic microfiltration membrane from mineral coal fly ash: application to the treatment of the textile dying effluents. Powder Technol 208:427-432. https://doi.org/ 10.1016/j.powtec.2010.08.039

Jepsen K, Bram M, Pedersen S, Yang Z (2018) Membrane fouling for produced water treatment: a review study from a process control perspective. Water 10:847. https://doi. org/10.3390/w10070847

Karnik BS, Davies SHR, Chen KC et al (2005) Effects of ozonation on the permeate flux of nanocrystalline ceramic membranes. Water Res 39:728-734. https://doi.org/10. 1016/j.watres.2004.11.017

Kavipriya M, Vennilamani N, Pattabhi S et al (2002) Utilization of various agricultural wastes for activated carbon preparation and application for the removal of dyes and metal ions from aqueous solutions. Bioresour Technol 87:129-132. https://doi.org/10.1016/s0960-8524(02)00 201-8

Kee TC, Bay HH, Lim CK et al (2015) Development of biogranules using selected mixed culture of decolorizing bacteria for the treatment of textile wastewater. Desalin Water Treat 54:132-139. https://doi.org/10.1080/ 19443994.2013.877853

Krivorot M, Kushmaro A, Oren Y, Gilron J (2011) Factors affecting biofilm formation and biofouling in membrane distillation of seawater. J Memb Sci 376:15-24. https://doi. org/10.1016/j.memsci.2011.01.061

Lee SA, Choo KH, Lee CH et al (2001) Use of ultrafiltration membranes for the separation of $\mathrm{TiO}_{2}$ photocatalysts in drinking water treatment. Ind Eng Chem Res 40:1712-1719. https://doi.org/10.1021/ie000738p

Lee M, Wu Z, Li K (2015) Advances in ceramic membranes for water treatment. In: Advances in membrane technologies for water treatment. Elsevier, pp 43-82

Lewandowski Z, Boltz JP (2010) Biofilms in water and wastewater treatment

Li Q, Jia R, Shao J, He Y (2019) Photocatalytic degradation of amoxicillin via $\mathrm{TiO}_{2}$ nanoparticle coupling with a novel submerged porous ceramic membrane reactor. J Clean Prod 209:755-761. https://doi.org/10.1016/j.jclepro.2018. 10.183

Liu CX, Zhang DR, He Y et al (2010) Modification of membrane surface for anti-biofouling performance: effect of anti-adhesion and anti-bacteria approaches. J Membr Sci 346:121-130. https://doi.org/10.1016/j.memsci.2009.09. 028

Lu C, Wu Y, Mai F et al (2009a) Degradation efficiencies and mechanisms of the ZnO-mediated photocatalytic degradation of Basic Blue 11 under visible light irradiation. J Mol Catal A Chem 310:159-165. https://doi.org/10.1016/ j.molcata.2009.06.011

Lu X, Liu L, Yang B, Chen J (2009b) Reuse of printing and dyeing wastewater in processess assessed by pilot-scale test using combined biological process and sub-filter technology. J Clean Prod 17:111-114. https://doi.org/10. 1016/j.jclepro.2008.03.003

Lu X, Yang B, Chen J, Sun R (2009c) Treatment of wastewater containing azo dye reactive brilliant red $\mathrm{X}-3 \mathrm{~B}$ using sequential ozonation and upflow biological aerated filter process. J Hazard Mater 161:241-245. https://doi.org/10. 1016/j.jhazmat.2008.03.077

Lucas MS, Dias AA, Sampaio A et al (2007) Degradation of a textile reactive Azo dye by a combined chemical-biological process: Fenton's reagent-yeast. Water Res 41:1103-1109. https://doi.org/10.1016/j.watres.2006.12. 013

Martin KJ, Nerenberg R (2012) The membrane biofilm reactor (MBfR) for water and wastewater treatment: principles, applications, and recent developments. Bioresour Technol 122:83-94. https://doi.org/10.1016/j.biortech.2012.02.110

Meabe E, Lopetegui J, Ollo J, Lardies S (2011) Ceramic membrane bioreactor: potential applications and challenges for the future. In: MBR Asia international conference, pp 1-9

Meng F, Chae SR, Drews A et al (2009) Recent advances in membrane bioreactors (MBRs): membrane fouling and membrane material. Water Res 43:1489-1512. https://doi. org/10.1016/j.watres.2008.12.044

Min S, Wang F, Han Y (2007) An investigation on synthesis and photocatalytic activity of polyaniline sensitized 
nanocrystalline $\mathrm{TiO}_{2}$ composites. J Mater Sci 42:9966-9972. https://doi.org/10.1007/s10853-007-2074$\mathrm{Z}$

Moon J, Yun CY, Chung KW et al (2003) Photocatalytic activation of $\mathrm{TiO}_{2}$ under visible light using Acid Red 44. Catal Today 87:77-86. https://doi.org/10.1016/j.cattod.2003.10. 009

Mozia S (2010) Photocatalytic membrane reactors (PMRs) in water and wastewater treatment. A review. Sep Purif Technol 73:71-91. https://doi.org/10.1016/j.seppur.2010. 03.021

Muhammad A, Shafeeq A, Butt MA et al (2008) Decolorization and removal of COD and BOD from raw and biotreated textile dye bath effluent through advanced oxidation processes (AOPS). Braz J Chem Eng 25:453-459. https://doi. org/10.1590/S0104-66322008000300003

Muthukumaran S, Baskaran K (2014) Comparison of the performance of ceramic microfiltration and ultrafiltration membranes in the reclamation and reuse of secondary wastewater. Desalin Water Treat 52:670-677. https://doi. org/10.1080/19443994.2013.826333

Naresh Yadav D, Anand Kishore K, Bethi B et al (2018) ZnO nanophotocatalysts coupled with ceramic membrane method for treatment of Rhodamine-B dye waste water. Environ Dev Sustain 20:2065-2078. https://doi.org/10. 1007/s10668-017-9977-x

Naresh Yadav D, Naz I, Anand Kishore K, Saroj D (2020) Evaluation of tire derived rubber (TDR) fixed biofilm reactor (FBR) for remediation of Methylene blue dye from wastewater. Environ Technol. https://doi.org/10.1080/ 09593330.2020.1737736

Oller I, Malato S, Sánchez-Pérez JA (2011) Combination of advanced oxidation processes and biological treatments for wastewater decontamination-a review. Sci Total Environ 409:4141-4166. https://doi.org/10.1016/j.scitotenv.2010. 08.061

Ong SA, Toorisaka E, Hirata M, Hano T (2008) Granular activated carbon-biofilm configured sequencing batch reactor treatment of C.I. Acid Orange 7. Dye Pigment 76:142-146. https://doi.org/10.1016/j.dyepig.2006.08.024

Ouasif H, Yousfi S, Bouamrani ML et al (2013) Removal of a cationic dye from wastewater by adsorption onto natural adsorbents. J Mater Environ Sci 4:1-10

Pal S, Sarkar U, Dasgupta D (2010) Dynamic simulation of secondary treatment processes using trickling filters in a sewage treatment works in Howrah, west Bengal, India. Desalination 253:135-140. https://doi.org/10.1016/j.desal. 2009.11.019

Pardeshi SK, Patil AB (2009) Effect of morphology and crystallite size on solar photocatalytic activity of zinc oxide synthesized by solution free mechanochemical method. J Mol Catal A Chem 308:32-40. https://doi.org/10.1016/j. molcata.2009.03.023

Paridah M, Moradbak A, Mohamed A et al (2016) We are IntechOpen, the world' s leading publisher of Open Access books Built by scientists, for scientists TOP $1 \%$. Intech i:13. https://doi.org/10.5772/57353

Park HO, Oh S, Bade R, Shin WS (2010) Application of $\mathrm{A}_{2} \mathrm{O}$ moving-bed biofilm reactors for textile dyeing wastewater treatment. Korean J Chem Eng 27:893-899. https://doi. org/10.1007/s11814-010-0143-5
Peng CUI, Xianzhi Z, Minjie Z, Longde W (2006a) Photocatalysis-membrane separation coupling reactor and its application. Chin J Catal 27:752-754

Peng F, Wang H, Yu H, Chen S (2006b) Preparation of aluminum foil-supported nano-sized $\mathrm{ZnO}$ thin films and its photocatalytic degradation to phenol under visible light irradiation. Mater Res Bull 41:2123-2129. https://doi.org/ 10.1016/j.materresbull.2006.03.029

Phugare SS, Kalyani DC, Patil AV, Jadhav JP (2011) Textile dye degradation by bacterial consortium and subsequent toxicological analysis of dye and dye metabolites using cytotoxicity, genotoxicity and oxidative stress studies. J Hazard Mater 186:713-723. https://doi.org/10.1016/j. jhazmat.2010.11.049

Pidou M, Parsons SA, Raymond G et al (2009) Fouling control of a membrane coupled photocatalytic process treating greywater. Water Res 43:3932-3939. https://doi.org/10. 1016/j.watres.2009.05.030

Pouretedal HR, Norozi A, Keshavarz MH, Semnani A (2009) Nanoparticles of zinc sulfide doped with manganese, nickel and copper as nanophotocatalyst in the degradation of organic dyes. J Hazard Mater 162:674-681. https://doi.org/ 10.1016/j.jhazmat.2008.05.128

Punzi M, Anbalagan A, Aragão Börner R et al (2015) Degradation of a textile azo dye using biological treatment followed by photo-Fenton oxidation: evaluation of toxicity and microbial community structure. Chem Eng J 270:290-299. https://doi.org/10.1016/j.cej.2015.02.042

Rasalingam S, Peng R, Koodali RT (2014) 617405.Pdf. 2014

Rodrigues CSD, Madeira LM, Boaventura RAR (2014) Synthetic textile dyeing wastewater treatment by integration of advanced oxidation and biological processes-performance analysis with costs reduction. J Environ Chem Eng 2:1027-1039. https://doi.org/10.1016/j.jece.2014.03.019

Romanos GE, Athanasekou CP, Katsaros FK et al (2012) Double-side active $\mathrm{TiO}_{2}$-modified nanofiltration membranes in continuous flow photocatalytic reactors for effective water purification. J Hazard Mater 211-212:304-316. https://doi.org/10.1016/j.jhazmat.2011. 09.081

Saha P, Shinde O, Sarkar S (2017) Phytoremediation of industrial mines wastewater using water hyacinth. Int J Phytoremediat 19:87-96. https://doi.org/10.1080/15226514. 2016.1216078

Saikia L, Bhuyan D, Saikia M et al (2015) Photocatalytic performance of $\mathrm{ZnO}$ nanomaterials for self sensitized degradation of malachite green dye under solar light. Appl Catal A Gen 490:42-49. https://doi.org/10.1016/j.apcata.2014. 10.053

Sehar S, Naz I (2016) Role of the biofilms in wastewater treatment. In: Microbial biofilms-importance and applications. InTech

Shah PD, Dave SR, Rao MS (2012) Enzymatic degradation of textile dye Reactive Orange 13 by newly isolated bacterial strain Alcaligenes faecalis PMS-1. Int Biodeterior Biode$\operatorname{grad}$ 69:41-50. https://doi.org/10.1016/j.ibiod.2012.01. 002

Sharma S, Bhattacharya A (2017) Drinking water contamination and treatment techniques. Appl Water Sci 7:1043-1067. https://doi.org/10.1007/s13201-016-0455-7 
Soares PA, Silva TFCV, Manenti DR et al (2014) Insights into real cotton-textile dyeing wastewater treatment using solar advanced oxidation processes. Environ Sci Pollut Res 21:932-945. https://doi.org/10.1007/s11356-013-1934-0

Şolpan D, Güven O, Takács E et al (2003) High-energy irradiation treatment of aqueous solutions of azo dyes: steadystate gamma radiolysis experiments. Radiat Phys Chem 67:531-534. https://doi.org/10.1016/S0969-806X(03)00 $100-2$

Song L, Zhu B, Jegatheesan V et al (2018) Treatment of secondary effluent by sequential combination of photocatalytic oxidation with ceramic membrane filtration. Environ Sci Pollut Res 25:5191-5202. https://doi.org/10.1007/ s11356-017-9070-x

Strunk J, Kähler K, Xia X, Muhler M (2009) The surface chemistry of $\mathrm{ZnO}$ nanoparticles applied as heterogeneous catalysts in methanol synthesis. Surf Sci 603:1776-1783. https://doi.org/10.1016/j.susc.2008.09.063

Suárez-Parra R, Hernández-Pérez I, Rincón ME et al (2003) Visible light-induced degradation of blue textile azo dye on $\mathrm{TiO} / \mathrm{CdO}-\mathrm{ZnO}$ coupled nanoporous films. Sol Energy Mater Sol Cells 76:189-199. https://doi.org/10.1016/ S0927-0248(02)00346-X

Tamboli DP, Kurade MB, Waghmode TR et al (2010) Exploring the ability of Sphingobacterium sp. ATM to degrade textile dye Direct Blue GLL, mixture of dyes and textile effluent and production of polyhydroxyhexadecanoic acid using waste biomass generated after dye degradation. J Hazard Mater 182:169-176. https://doi.org/10.1016/j.jhazmat. 2010.06.011

Ullah R, Dutta J (2008) Photocatalytic degradation of organic dyes with manganese-doped $\mathrm{ZnO}$ nanoparticles. J Hazard Mater 156:194-200. https://doi.org/10.1016/j.jhazmat. 2007.12.033

van Belkum A (2007) The biofilm mode of life. J Microbiol Methods 71:348-349. https://doi.org/10.1016/j.mimet. 2007.09.008

Van Geluwe S, Braeken L, Van der Bruggen B (2011) Ozone oxidation for the alleviation of membrane fouling by natural organic matter: a review. Water Res 45:3551-3570. https://doi.org/10.1016/j.watres.2011.04.016

Van Leeuwen KVL (1996) Technical guidance document on risk assessment in support of commission directive 93/67/ EEC on risk assessment for new notified substances and commission regulation (EC) No1488/94 on risk assessment for existing substances Part II. Euro Commun 1-337

Venkatachalam N, Palanichamy M, Arabindoo B, Murugesan V (2007) Enhanced photocatalytic degradation of 4-chlorophenol by $\mathrm{Zr} 4+$ doped nano $\mathrm{TiO}_{2}$. J Mol Catal A Chem 266:158-165. https://doi.org/10.1016/j.molcata. 2006.10.051
Wang H, Xie C, Zhang W et al (2007) Comparison of dye degradation efficiency using $\mathrm{ZnO}$ powders with various size scales. J Hazard Mater 141:645-652. https://doi.org/ 10.1016/j.jhazmat.2006.07.021

Wang WY, Irawan A, Ku Y (2008) Photocatalytic degradation of Acid Red 4 using a titanium dioxide membrane supported on a porous ceramic tube. Water Res 42:4725-4732. https://doi.org/10.1016/j.watres.2008.08.021

Wang Y, Qiu L, Qiu Q (2018) Development of ceramic membrane combination process in the treatment of industrial wastewater in China. IOP Conf Ser Mater Sci Eng 392:022039. https://doi.org/10.1088/1757-899X/392/2/ 022039

Webb J (2009) Differentiation and dispersal in biofilms. Bact Biofilm Form Adapt 1996:1-8

Wu X, Su P, Liu H, Qi L (2009) Photocatalytic degradation of Rhodamine B under visible light with Nd-doped titanium dioxide films. J Rare Earths 27:739-743. https://doi.org/10. 1016/S1002-0721(08)60326-9

Xu L, Li W, Lu S et al (2002) Treating dyeing waste water by ceramic membrane in crossflow microfiltration. Desalination 149:199-203. https://doi.org/10.1016/S00119164(02)00759-2

Yaseen DA, Scholz M (2019) Textile dye wastewater characteristics and constituents of synthetic effluents: a critical review. Int J Environ Sci Technol 16:1193-1226. https:// doi.org/10.1007/s13762-018-2130-z

Yu JC, Ho W, Yu J et al (2005) Efficient visible-light-induced photocatalytic disinfection on sulfur-doped nanocrystalline titania. Environ Sci Technol 39:1175-1179. https://doi. org/10.1021/es035374h

Zhang H, Quan X, Chen S et al (2006a) Fabrication of photocatalytic membrane and evaluation its efficiency in removal of organic pollutants from water. Sep Purif Technol 50:147-155. https://doi.org/10.1016/j.seppur. 2005.11.018

Zhang H, Quan X, Chen S, Zhao H (2006b) Fabrication and characterization of silica/titania nanotubes composite membrane with photocatalytic capability. Environ Sci Technol 40:6104-6109. https://doi.org/10.1021/ es060092d

Zhao Y, Lu D, Cao Y et al (2018) Interaction analysis between gravity-driven ceramic membrane and smaller organic matter: implications for retention and fouling mechanism in ultralow pressure-driven filtration system. Environ Sci Technol 52:13718-13727. https://doi.org/10.1021/acs.est. $8 \mathrm{~b} 03618$

Publisher's Note Springer Nature remains neutral with regard to jurisdictional claims in published maps and institutional affiliations. 